was unimpaired, he felt keenly the sense of isolation which this engendered. The extent to which be prized personal contacts can be gauged from a passage in one of his letters, written in 1937: "the tragedy of age, and the only one that hurts is the loss of friends whom one has survived". We too have suffered the loss of a much-valued friend, and science one who served her well. E. J. SAlisbury.

\section{Flight-Lieut. J. A. Moy-Thomas}

$B y$ the death, in a motor accident while on duty, on February 29, of Flight-Lieut. J. A. Moy-Thomas at the age of thirty-five, we have lost one of the most distinguished of the younger generation of zoologists. The study of fossil fishes attracted him most, and he made many valuable contributions to our knowledge of their structure and classification. Particularly did he devote himself to unravelling the difficult problem of the true affinities of certain well-known forms of very obscure relationship.

A pupil of Archer Vassal at Harrow School, he obtained a scholarship at Christ Church, and read honours in both zoology and geology at Oxford. His first published research was on the development and attachment of teeth in fishes (Quart. J. Roy. Micro. Soc., 76 ; 1934). There followed a series of memoirs on Chondrenchelys, Pristychius, Petrodus and other early shark-like forms, many of which he had collected himself during his expeditions to Scotland and elsewhere. These researches threw much light on the evolution of the Selachii and Bradyodonti including Holocephali. Already, in 1934 (Proc. Zool. Soc.), he had pointed out the affinity that very aberrant Palæoniscid, called Tarrasius by Traquair, may have with the living Polypterus (of which he had published a description of the chondrocranium), and thence passed to the detailed study of Palæoniscids in another series of memoirs not yet completely published. In the course of this work he brought out several papers in collaboration with E. I. White, of the British Museum, and Miss Bradley Dyne. With the same admirable powers of observation and happy interpretation he next dealt with the Coelacanths, and described those of Madagascar. In 1939 he joined an expedition to Greenland to collect material with his intimate friend Prof. E. A. Stensiö of Stockholm.

Particularly important and characteristic of his careful method of dealing with difficult material is Moy-Thomas's work on Palæospondylus, recently published (Phil. Trans. Roy. Soc.; 1940). This little fish from the Mid-Devonian of Scotland has been a puzzle to all observers since Traquair first described it in 1890 and assigned it to the Cyclostomes. This interpretation was generally accepted, though some believed it to be a larval form of some higher fish or even amphibian. Moy-Thomas, after examining a vast number of specimens, rejected the larval theory as inconsistent with the presence of well-formed vertebral centra and the condition of the elements of the skull, and also was unable to confirm the presence of many alleged Cyclostome characters. More important still, he discovered that the tail had hitherto been misinterpreted, had been described upside down, and was really heterocercal with a larger ventral Iobe supported by jointed radials; he also provided good evidence of the presence of paired fins, and of jaws. Thus he seems to have established that Palæospondylus belongs to the Gnathostomes. Fortunately, the most important results of these various researches were embodied in his excellent little book on "Palæozoic Fishes" (1939), published just before the War.

Deeply interested in the comparison of the dermal bones of the skull in the various groups of Osteichthyes and Tetrapoda and the tracing of their homologies, Moy-Thomas was not content with mere observation and description, but tried by experimental methods practised on living forms to discover the causes which may influence their shape, size and number. Already in 1941 he had reached important results on the rainbow trout, and concluded that, contrary to earlier theories, the origin of such bones is not due to the presence of the sense organs of the lateral line system or of the central nervous system (NATURE, May 31, 1941, p. 681).

Moy-Thomas began his teaching career under Prof. W. Garstang at Leeds, where he went soon after taking his degree. Returning to Oxford, he was made University demonstrator and lecturer in the Department of Zoology and Comparative Anatomy in 1933, and also became the first holder of the fellowship founded by the late E. T. Browne at the Queen's College.

Moy-Thomas's love of accuracy and his excellent memory made him a most successful teacher and tutor. But his influence on his pupils was not only academic. Possessed of great gaiety, sense of humour and zest of life, he was a continual source of stimulation and pleasure to everyone who knew him. With these attractive gifts he could make criticism, not only of their work but also of their life and manners, acceptable to his pupils.

Thus by this tragic accident has been cut short the life of one who will be much regretted by colleagues and many friends in Oxford and elsewhere. $\mathrm{He}$ leaves behind his wife and two children.

\section{E. S. GOODRICH.}

\section{Prof. H. Buisson}

Henri Buisson, professeur de physique générale à l'Université de Marseille, est mort le 6 Janvier 1944 à l'âge de 70 ans, après une courte maladie. Il s'était fait connaître par de nombreux travaux sur l'optique, souvent avec Charles Fabry (métrologie interférentielle, repères spectroscopiques formant le 'système international des longueurs d'onde', photométrie, 'équivalent mécanique de la lumière', etc.). Depuis 1912, il s'était consacré, avec Fabry, à l'étude de l'ozone atmosphérique, travail qui avait été l'origine de nombreuses recherches, principalement en France (Cabannes, Dufay, Gauzit, Chalonge, Vassy, etc.) et en Angleterre (Dobson et ses collaborateurs).

Ch. Fabry.

The work of MM. Fabry and Buisson on atmospheric ozone was the foundation of all later work on the subject. It had been suggested that the remarkably sudden 'cut off' of the solar spectrum at about $3000 \mathrm{~A}$. was due to absorption in the earth's atmosphere. To test this hypothesis, they made careful measurements of the absorption by ozone of light of different wave-lengths in the laboratory and compared this with the extinction of sunlight passing through the atmosphere. From these measurements they were able to confirm the hypothesis, and also showed that the total amount of ozone in the atmosphere was equivalent to a layer of pure gas about $3 \mathrm{~mm}$. thick. 
In addition, Prof. Buisson made regular daily measurements of the amount of ozone in the atmosphere at Marseilles and also showed that the amount of ozone in surface air was relatively very small.

The importance of ozone in the upper atmosphere lies in the fact that, together with carbon dioxide and water vapour, it probably governs the radiative equilibrium temperature at great heights, and is largely responsible for the existence of the upper warm region at a height of $50-70 \mathrm{~km}$., where the temperature is probably above that at ground-level. For these reasons the names of Fabry and Buisson are familiar to meteorologists the world over.

G. M. B. Dobson.

\section{Dr. E. Granichstadten}

Dr. E. Granichstadten died at Edinburgh on January 5, 1944. He was one of Austria's most successful industrial chemists, possessing the rare ability both to make discoveries and to apply them; he was also a great benefactor to science. His most outstanding contribution to chemistry was the development of the catalytic hydrogenation of oils and fats which made margarine manufacture possible. Shortly after Sabatier and Senderens had demonstrated that unsaturated hydrocarbons in the gaseous phase could be hydrogenated in the presence of a nickel catalyst, Dr. Granichstadten began his experiments on the transformation of vegetable oils into edible fats. After many difficulties he finally succeeded by passing electrolytic hydrogen through the highly purified oils into which the catalyst had been introduced as a readily reducible nickel salt, a process which found wide industrial application in most European countries.

In later years Dr. Granichstadten founded and endowed a research institute at the Alpine spa Gastein with the view of putting the renowned effects of its radioactive springs on a scientific basis. Spectacular progress had been made by the time Austria was invaded. Within three days of the invasion, Dr. Granichstadten was forbidden to enter his own institute, and shortly afterwards he was driven from his native country. He found refuge at Edinburgh, where he was engaged in experiments on nutrition until his premature death.

M. F. Perutz.

WE regret to announce the following deaths:

Sir Charles Boys, F.R.S., on March 30, aged eighty-nine.

Sir Cecil Harcourt-Smith, K.C.V.O., formerly keeper of Greek and Roman Antiquities, British Museum, director of the British School at Athens during 1895-97, and director of the Victoria and Albert Museum during 1909-24, on March 27, aged eighty-four.

Sir Thomas Lyle, F.R.S., formerly professor of natural philosophy in the University of Melbourne, aged eighty-three.

Prof. L. R. Wilberforce, professor of physics in the University of Liverpool during 1900-35, on April 1, aged eighty-two.

\section{NEWS and VIEWS}

\section{Parliamentary and Scientific Committee}

THE annual report for 1943 of the Parliamentary and Scientific Committee refers to a substantial increase in membership. Subjects with which the Committee was concerned during the year included income tax and subscriptions to learned societies, coal utilization research, the training of Civil servants, scientific research and the universities in post-war Britain, on the last three of which reports have been issued, research and Colonial development and income tax and research expenditure, on which a memorandum has since been issued. Further action is projected in regard to the universities and research. A motion has been tabled by members of the Committee in the House of Commons which, it is hoped, may provide the opportunity for a debate during the current session, while a sub-committee has been set up to report on the general question of how research in Great Britain might be developed and organized in the most efficient manner. At the annual general meeting held on February 3, 1944, the chairman reported that it was hoped that the first report would cover a general introduction as to the principles which should be applied to the organization and development of all fields of research work and the development of industrial research. Further reports might concentrate on research and agriculture, research and housing, etc.

At the annual luncheon on the same day, Lord Samuel, after referring to the presence in the Government of four men who had undergone scientific train- ing at the universities, suggested that the Lord President of the Privy Council should have his functions enlarged so that he might become the representative of science as such in the Cabinet and among the other Departments. Lord Woolton paid a warm tribute to the work of the Committee, emphasizing that it is by the application of scientific discovery to the ordinary everyday life of the people that we raise the standard of life of the whole com. munity, and referring particularly to what had been done in recent years with regard to food. Sir Raymond Streat suggested that the immense enlargement of the areas of fundamental knowledge and the increasing tendency for society to demand from science the attainment of specific objectives are leading us into an age of applied research. To meet that challenge, we have not so much to extend the quality and volume of our scientific work as our organization to develop and apply it, and to evolve modifications of our social, political, economic and legislative framework so that we may absorb the impact of an era of research and increase the health and vigour of our society. In connexion with the last, British natural conservatism is our danger. To what extent are our ideas of social security, our instinctive reluctance to acknowledge obsolescence, our regard for property, our trade union practices, inimical to rapid absorption of the consequences of scientific progress ? Every effort should be made to prepare the public for the pace at which society must absorb the fruits of scientific work. 